\title{
Dependence of productivity of spring rape on seeding rates, time and methods of sowing in conditions of the Northern Steppe
}

\author{
Yu. Kuksa, \\ I. Komarova \\ Candidate of Agricultural Sciences Institute of Oilseeds of NAAS
}

The purpose. To study efficiency of effect of seeding rate, time and method of sowing on productivity of seeds of spring rape in the Northern steppe. Methods. Field, calculation-mathematical, statistical. Results. Influence on productivity of spring rape is determined of 3 different times of sowing depending on temperature of soil; 5 seeding rates; gutter $(15 \mathrm{~cm})$ and wide-row $(45$ and $60 \mathrm{~cm})$ sowing. Optimum parameters of the investigated factors are fixed. The conducted correlation analysis has displayed that dependence of productivity of spring rape is inverse to all examined factors. Conclusions. Investigated factors essentially influence the level of productivity of spring rape. The optimum time of sowing for deriving maximum yield at gutter sowing is that one when the temperature of soil is $4-6^{\circ} \mathrm{C}$, the seeding rate should be 2 million seeds for 1 hectare. At wide-row sowing the maximum productivity is gained at seeding rate $1-$ 1,5 million seeds for 1 hectare. The third time of sowing is unfavorable and cannot be recommended for growing spring rape.

Key words: spring rape, time of sowing, temperature of soil, seeding rate, width of row, productivity.

Introduction. Under the conditions of the northern Steppe of Ukraine, winter rape forms a greater yield than the spring crop, due to the use of moisture accumulated during the autumn-winter period.It is less damaged by pests, as during the period of their massive appearance of winter rape plants are almost formed. But sometimes the amount of moisture in the soil in the fall is insufficient for germination of seeds and the formation of a developed rosette [1]. In this case, spring rape, which due to environmental plasticity can be grown in areas risky for growing winter rape, is an insurance culture to produce vegetable oil [2,3].

Widespread introduction of spring rape with the realization of its potential in the conditions of the northern steppe of Ukraine requires a detailed study of the characteristics of agricultural technology for its cultivation $[4,5]$.

Therefore, in order to develop the main agro-measures for growing spring rape in this agro-climatic zone, we investigated the effectiveness of their effect on seed yield.

Material and research methods. Field research was carried out in 2012-2014 on the fields of the FG "Ahroyednist", located on the right bank of the Pridneprov Plateau near the village Zapolichki, Verkhnodniprovsky district of Dnipropetrovsk region.

The soil cover of the experimental plots, the area of which was $50 \mathrm{~m}^{2}$, typical for this area, is represented by ordinary black soil with a humus heavy-sandy, with a thickness of humus $60-65 \mathrm{~cm}$. Field after harvesting the predecessor was prepared according to the system of improved autumn plowing.

The subject of research was spring rapeseed variety Obriy, 00-type, breeding of Institute of oilseed crops NAAS [6]. Repeated trials is four times. The investigated factors, which characterize the corresponding agro measures, in the three-factor experiment were: the time of sowing, seeding rates and the row spacing.

Sowing was carried out in three terms (factor A): first on soil temperature $4 \ldots 6^{\circ} \mathrm{C}$, second $-6 \ldots 8^{\circ} \mathrm{C}$ and third $-8 \ldots 10^{\circ} \mathrm{C}$. Three methods of sowing (factor $\mathrm{B}$ ) were also investigated: a row (with a row spacing of 15 $\mathrm{cm}$ ), a wide-row with a spacing between rows of $45 \mathrm{~cm}$ and $60 \mathrm{~cm}$; and five sowing norms (factor $\mathrm{C}$ ): 1,0; 
$1.5 ; 2.0 ; 2.5 ; 3.0$ million seed per hectare. The statistical processing of the results is performed using the appropriate modules of the application package Statistica [7].

Research results. The yield of spring rape varies considerably over the years of research, due to its dependence on the level of moisture during the growing season. But every year the first seeding period was the best (table 1). In 2012 the yield did not exceed $0.94 \mathrm{t} / \mathrm{ha}$, in $2014-1.89 \mathrm{t} / \mathrm{ha}$. The maximum yield was formed in 2013 (the first sowing period, with a row spacing of $15 \mathrm{~cm}$, at the sowing rate of 2.0 million seeds per ha) and amounted to $1.96 \mathrm{t} / \mathrm{ha}$. On average, for three years of planting, at the first sowing period the productivity was from 0.97 to $1.58 \mathrm{t} / \mathrm{ha}$, at the second - from $0.78 \mathrm{t} / \mathrm{ha}$ to $1.23 \mathrm{t} / \mathrm{ha}$, at the third - from $0.37 \mathrm{t} / \mathrm{ha}$ to $0.90 \mathrm{t} / \mathrm{ha}$. The third third seeding period was the most unfavorable. The effect of the sowing method and sowing norms did not play a decisive role in yield formation, but are significant and should be taken into account in predicting it.

Table 1. Dependence of spring rapeseed yield on sowing norms, times and methods of sowing ( 2012-2014)

\begin{tabular}{|c|c|c|c|c|c|c|c|c|c|c|c|c|c|}
\hline \multirow{3}{*}{$\begin{array}{l}\text { Row } \\
\text { spacing, } \\
\text { cm } \\
\text { (B) }\end{array}$} & \multirow{3}{*}{$\begin{array}{l}\text { Seeding } \\
\text { rate, } \\
\mathrm{mln} / \mathrm{ha} \\
(\mathrm{C})\end{array}$} & \multicolumn{12}{|c|}{ Yield, t/ha } \\
\hline & & \multicolumn{8}{|c|}{$\begin{array}{c}\text { period } \\
\left(4 \ldots 6^{\circ} \mathrm{C}\right)\end{array}$} & \multicolumn{4}{|c|}{) $\mid \begin{array}{ll}\text { III } & \text { period } \\
\left(8 \ldots 10^{\circ} \mathrm{C}\right)\end{array}$} \\
\hline & & ำ & $\stackrel{m}{\stackrel{2}{\alpha}}$ & $\stackrel{+}{\grave{N}}$ & mean & $\stackrel{N}{\circ}$ & 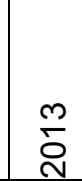 & 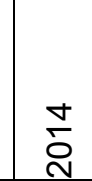 & mean & $\stackrel{N}{\grave{N}}$ & $\stackrel{m}{i}$ & $\stackrel{\nabla}{\stackrel{N}{N}}$ & mean \\
\hline \multirow{5}{*}{15} & 1,0 & 0,69 & 1,62 & 1,72 & 1,34 & 0,28 & 1,53 & 1,49 & 1,10 & 0 & 1,29 & 1,38 & 0,89 \\
\hline & 1,5 & 0,81 & 1,89 & 1,89 & 1,53 & 0,36 & 1,71 & 1,63 & 1,23 & 0 & 1,26 & 1,43 & 0,90 \\
\hline & 2,0 & 0,94 & 1,96 & 1,83 & 1,58 & 0,26 & 1,67 & 1,55 & 1,16 & 0 & 1,12 & 1,31 & 0,81 \\
\hline & 2,5 & 0,91 & 1,73 & 1,70 & 1,45 & 0,24 & 1,61 & 1,44 & 1,10 & 0 & 0,95 & 1,19 & 0,71 \\
\hline & 3,0 & 0,75 & 1,55 & 1,67 & 1,32 & 0,15 & 1,42 & 1,31 & 0,96 & 0 & 0,87 & 1,07 & 0,65 \\
\hline \multirow{5}{*}{45} & 1,0 & 0,89 & 1,71 & 1,69 & 1,43 & 0,38 & 1,61 & 1,55 & 1,18 & 0 & 1,23 & 1,28 & 0,84 \\
\hline & 1,5 & 0,91 & 1,75 & 1,72 & 1,46 & 0,35 & 1,65 & 1,57 & 1,19 & 0 & 1,21 & 1,29 & 0,83 \\
\hline & 2,0 & 0,76 & 1,62 & 1,66 & 1,35 & 0,29 & 1,52 & 1,44 & 1,08 & 0 & 1,09 & 1,13 & 0,74 \\
\hline & 2,5 & 0,69 & 1,59 & 1,53 & 1,27 & 0,23 & 1,47 & 1,39 & 1,03 & 0 & 0,99 & 1,09 & 0,78 \\
\hline & 3,0 & 0,55 & 1,37 & 1,28 & 1,07 & 0,17 & 1,29 & 1,12 & 0,86 & 0 & 0,91 & 0,80 & 0,57 \\
\hline \multirow{5}{*}{60} & 1,0 & 0,83 & 1,63 & 1,57 & 1,34 & 0,33 & 1,53 & 1,47 & 1,11 & 0 & 1,17 & 1,15 & 0,77 \\
\hline & 1,5 & 0,75 & 1,58 & 1,48 & 1,27 & 0,27 & 1,49 & 1,43 & 1,06 & 0 & 1,09 & 1,13 & 0,74 \\
\hline & 2,0 & 0,69 & 1,44 & 1,39 & 1,17 & 0,22 & 1,35 & 1,29 & 0,95 & 0 & 1,03 & 1,02 & 0,68 \\
\hline & 2,5 & 0,66 & 1,35 & 1,25 & 1,09 & 0,17 & 1,23 & 1,18 & 0,86 & 0 & 0,88 & 0,77 & 0,55 \\
\hline & 3,0 & 0,58 & 1,19 & 1,13 & 0,97 & 0,14 & 1,18 & 1,02 & 0,78 & 0 & 0,62 & 0,49 & 0,37 \\
\hline
\end{tabular}

minimum significant difference ${ }_{05}$ for the factor "period of sowing" 0,027

minimum significant difference $e_{05}$ for the factor "sowing norm" 0,034

minimum significant difference ${ }_{05}$ for the factor "row spacing" 0,027

According to the results of the dispersion analysis [8], the greatest effect on the rapeseed productivity has been found to have of the sowing period $-73,5 \%$, the proportion of the sowing norms and the width of the row spacing are equal respectively $14,2 \%$ i $8,7 \%$. All three of the investigated factors have a statistically significant effect on the yield of rape. The working capacity of the dispersion model is 0.962 .

The correlation analysis [9] showed that the dependence of the spring rape yield is inverse to all the factors studied. At the same time, its high level (on the Chaddock scale) is noted $r=-0,86 \pm 0,16$ with the term of sowing and moderate (при $r=-0,35 \pm 0,29$ ) with the norm of sowing. In both cases, the level of statistical significance does not exceed 0.02 , that is, it is less than the level of significance we have adopted $\alpha=0,05$. 
The correlation coefficient between the crop yield and the width of the row spacing is $r=-0,28 \pm 0,30$ for $p=0,065$.

In the regression analysis [10] the dependence of crop yield on the investigated factors - soil temperature, width of row spacing and sowing norms, a mathematical model in the form of the second-order response function, given with the consideration of the significance of the regression coefficients, is estimated according to the Student's t-criterion (1)

$M=1,37+0,33 z+0,01 b-0,002 z b-0,01 t^{2}-0,09 z^{2}-1,32 \cdot 10^{-4} b^{2},(1)$

where $\quad \boldsymbol{M}$ - yield, $\boldsymbol{t}$ - soil temperature, $\boldsymbol{b}$ - width of row spacing, $\boldsymbol{z}$ - sowing norm

The statistical characteristic of this equation shows that the mathematical model obtained is adequate, since the significance level of the $\boldsymbol{F}$ - criterion of Fisher is $\boldsymbol{p}=2,054 \cdot 10^{-28}$, that is, less than the adopted level of significance $\alpha$ and is working capacity, since the determination coefficient of the equation is $R^{2}=0,987$ exceeding the limit of 0.75 .

From the analysis of the equation (1) on the extremum we have that the maximum seed yields $(1.47 \mathrm{t} /$ ha) on the first time of sowing, for the width of row spacing $15 \mathrm{~cm}$ and the norm of sowing 1.67 million germinated seeds per hectare.

The evaluation of the laws of the influence of factors should be illustrated with the help of graphical representation of the surface of the response of the pair of interactions of the factors given in Fig. 1. There is a sharp decrease in the yield of rape with increasing temperature of the soil, which is associated with the timing of sowing, and with an increase in seed rate to 3 million seeds. (Fig.1 a). 


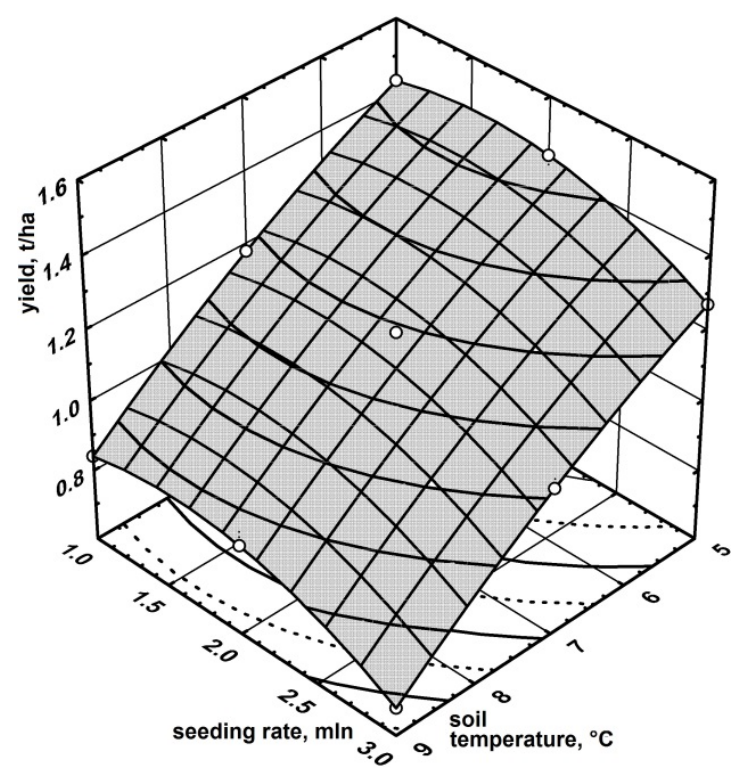

a)

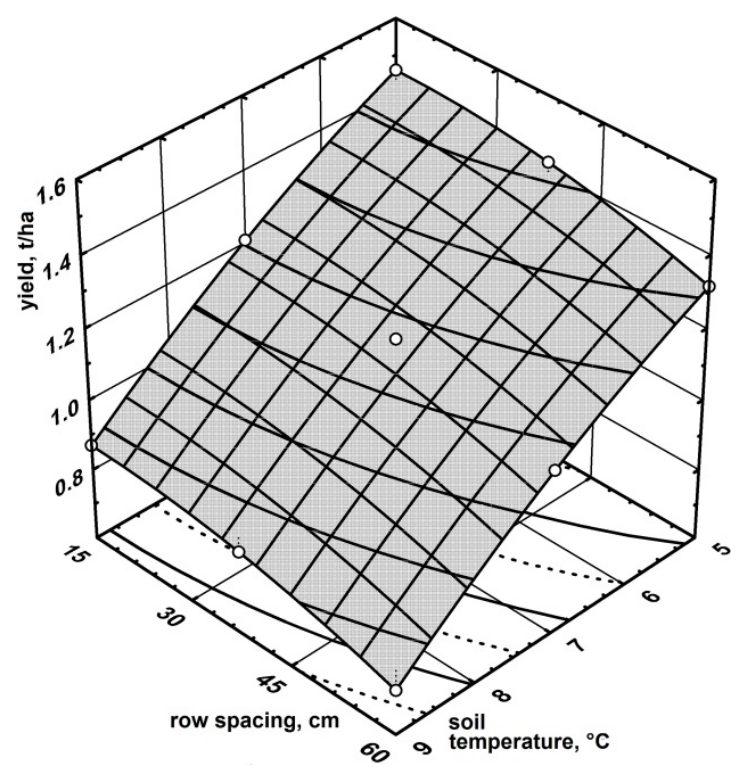

b)

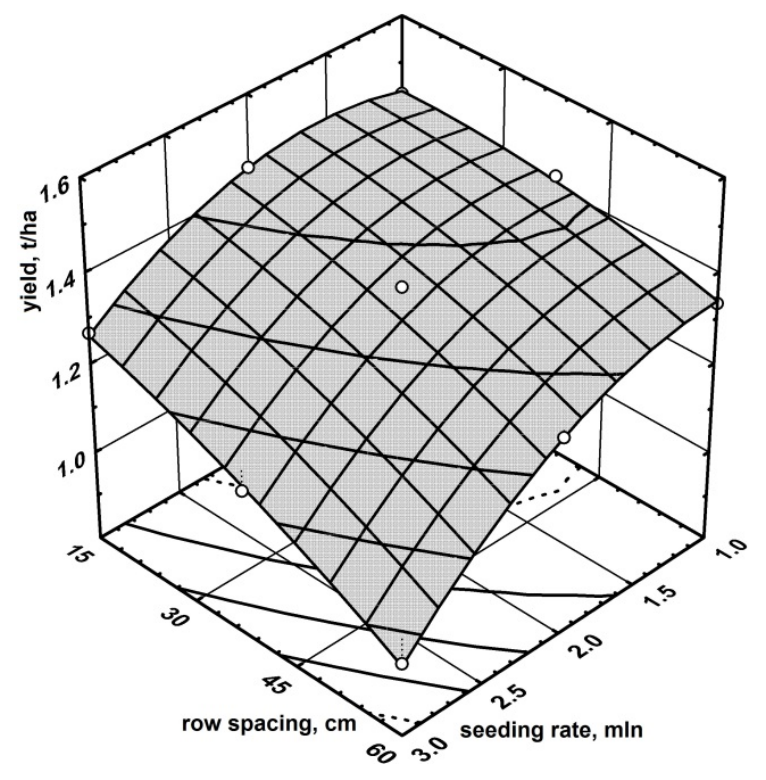

c)

Fig. 1. Surface of the response of pair combinations of the dependence of rapeseed yield on the investigated factors: a - time of sowing and seeding rate; $b$ - time of sowing and row spacing; $c$ - seeding rate and row spacing.

But for the first sowing period, the maximum yield is formed at a seed rate of 1.5-2.0 million seeds per hectare and is about $1.5 \mathrm{t} / \mathrm{ha}$, with increasing seed rates, yields are reduced, but remains fairly high (more than $1.2 \mathrm{t} / \mathrm{ha}$ ) compared with other sowing dates. During the third sowing date, the dependence of crop yields on sowing rates is substantially increased and generally has a curvilinear character. The maximum yield is obtained at the seed rate of 1.0-1.5 million seeds per hectare and is rapidly reduced with an increase in the number of plants per unit area. Almost linear decrease of yield with increase of inter-row width and increase of soil temperature during sowing (Fig. 1b). With a row spacing of $15 \mathrm{~cm}$ is the best to sow any time. It is possible to use a wide-row method of sowing for the first and second periods, while in the third date of seedings with rows spacing of 45 and $60 \mathrm{~cm}$, the yield significant decreased.

The dependence of the rapeseed yield on the interaction of the factors of the seed rate and the method of seeding is reflected in Fig. $1 \mathrm{c}$. In the linear method of sowing, there is a slight variation in yields at its 
maximum value for the seed rate of 1.5-2.0 million seeds per hectare. This is due to the even distribution of plant nutrition. In the broad-row method of sowing, the highest yield is obtained at a seed rate of 1.0-1.5 mln per hectare. Simultaneous increase in row spacing and seeding rates leads to intensive moisture evaporation and increased competition between plants for nutrients and moisture content.

\section{Conclusions.}

Research factors significantly affect the level of productivity of spring rape. The optimal time for obtaining the maximum yield level is the sowing period at soil temperature $4 \ldots 6^{\circ} \mathrm{C}$, in line mode, with a seeding rate of 2.0 million seeds per ha. The third seeding period is unfavorable and cannot be recommended for the cultivation of spring rape.

\section{Bibliography}

1. Собко М. Г. Роль агроприйомів вирощування ярого ріпаку / М. Г. Собко,О. Г. Полежай, А. В. Мельник // Науково-технічний бюлетень ІОК УААН. - Запоріжжя, 2009. - Вип. 14. - С. 218-225.

2. СайкоВ. Ф. Рекомендації з вирощування ріпаку ярого та гірчиці білої / [В.Ф. Сайко, В. Ф. Камінський, П. С. Вишнівський та ін.] К.: Колобіг, 2005. - 36 с.

3. SidlauskasG., Bernotas S. Some factors affecting seed yield of spring oilseed rape (Brassica napus L.) Agronomy Research 1(2).- 2003. - p. 229-243.

4. Терещенко Н.М. Особливості технології вирощування ріпаку ярого в умовах центрального Лісостепу / Терещенко Н.М. // Вісник аграрної науки. - 2001. -№ 7. - С. 72-74.

5. Ківер В.X. Ріпак у Північному Степу України: значення, спектр використання та перспективи виробництва / Ківер В.Х., Амрозяк Ю.В., Маслікова К.П. // Вісник аграрної науки Причорномор'я, Спец. випуск 4 том 1, 2006. - С. 101-105.

6. Плетень С.В.Перспективи розвитку ріпаківництва в Україні / [ С. В. Плетень, В. В. Рожкован, В. Г. Виновец, І. Б. Комарова, Є. В. Гайдаш] // Науково-виробничий щорічник "Посібник українського хлібороба”. - М-во аграрної політики України, НААНУ, Інститут рослинництва ім. В.Я. Юр’єва. - 2009. - c. 64-65.

7. Боровиков B. STATISTICA. Искусствоанализаданных на компьютере: Для профессионалов. 2-е изд. (+CD)/ В. Боровиков - СПб.: Питер, 2003. - 688 с.

8. Ушкаренко В. О. Статистичний аналіз результатів польових дослідів у землеробстві: Монографія. / [ Е. О. Ушкаренко, Р. А. Вожегова, С. П. Голобородько, С. В. Коковіхін] - Херсон: Айлант, 2013. - 378 c.

9. Подання результатів математичної та статистичної обробки даних медичних та біологічних досліджень у дисертаційних роботах / [Сердюк А. М., Антомонов М. Ю., Бардов В. Г., Прилуцький О. С.] // Бюлет. Вищої атестац. комісії України. - 2010. - № 6. - С. 31-33.

10. Основи наукових досліджень в агрономії / [ В. О. Єщенко, П. Г. Копитко, П. В. Костогриз, В. П. Опришко ] . За ред. В. О. Єщенка. — Вінниця: ПП “ТД “Едельвейс і К”, 2014. - 332 с. 